\title{
Nicholas V. Riasanovsky, 1923-2011
}

Nicholas V. Riasanovsky, arguably the single most recognized name in the field of Russian history over the past half century, died at the age of 87 on 14 May 2011 in Oakland, California. The numerous obituaries that have already appeared have attested to his astonishing influence on our field. He was the author of several important studies of Russian intellectual history, most notably Russia and the West in the Teaching of the Slavophiles: A Study of Romantic Ideology (1952), A Parting of Ways: Government and the Educated Public in Russia, 1801-1855 (1976), and The Image of Peter the Great in Russian History and Thought (1985), as well as monographs on Charles Fourier, European Romanticism, and Russian identity. His most remarkable contribution in print is his History of Russia, a textbook that first appeared in 1962, and which remains, fifty years later, the standard-bearer in our field. Literally tens of thousands (possibly hundreds of thousands) of English-speaking undergraduates learned their Russian history through this History, and those numbers show no sign of abating.

Both in his family and in his formal education Nick constituted a living link to the heritage upon which all of our work still relies. He was born in Harbin, China, a center of the White emigration, on 21 December 1923. Both of his parents were important intellectuals, and Nick made it a point to acknowledge with considerable pride the influence of each of them on his own intellectual development. His father, Valentin, had been a professor of law at St. Petersburg (later Petrograd University) who had authored important works on customary law among the Mongols and on Russian intellectual history. Nick's mother, Antonia, was a celebrated novelist who wrote under the pen name of Antonia Fedorovna. Anyone who visited Nick's home in the Berkeley hills will recall seeing both of their works on prominent display.

The family emigrated to Eugene, Oregon, in 1938, and Nick received his BA at the University of Oregon. During World War II, he served in military intelligence. After the war, he returned to the United States to begin graduate study, first at Harvard, under the direction of Michael Karpovich, and then at Oxford, where he received his D. Phil while working with Isaiah Berlin and B. H. Sumner. Nick became part of a remarkable cohort of young scholars, including several other émigrés from Europe, who collectively created the field of Russian history in the United States as a serious and significant discipline. The highly charged and politicized atmosphere of the Cold War created the impetus and funding that made it possible for Russian studies to grow so prominent within American academia. But it was this small group of scholars-including Marc Raeff, Martin Malia, Richard Pipes, Leopold Haimson, Donald Treadgold, and Nick-who designed the programs and trained the legions of graduate students who went on to careers in universities across the country. Strong-willed and often highly opinionated, they fiercely debated the great interpretive issues of the time: What was the nature of Russia (did it have a nature)? How did it fit into modernity? How should we understand 1917? And, above all, what was the legacy of the Russian intelligentsia? Although often at odds, they shared a dedication, passion, and rigor that set a high bar for those of us who followed. This country is indeed fortunate that these individuals were at the ready during those fraught and heady times and that they insisted upon such high standards of scholarship and integrity.

As an intellectual mentor Nick eschewed the grand, universal, and often overdetermined theorizing that others embraced. His distaste for Stalinism and the Soviet system in general was crystal clear, but he preferred to convey his views through understatement and personal observation rather than as proclamation. He never spoke of a deus ex machina, never romanticized, and if he had any sense of an ideal personality (such as Isaiah Berlin's view of Aleksandr Herzen) or epoch in Russian history he never let on. The closer one worked with him the more one recognized his abiding devotion to ideas and their history, Geistesgeschichte in the classic sense. This was true both for his reading of the intelligentsia and his approach to historiography. Good ideas and good questions, he reminded us, were not just the province of youth. The seemingly old-fashioned scholars of generations past

Slavic Review 70, no. 4 (Winter 2011) 
could productively inform and direct our thinking if only we would maintain the patience and good sense to actually read them.

Nick began his teaching career at the University of Iowa, and it was there that he met the love of his life, Arlene, with whom he raised their three children, Nick Jr., Maria, and John. In 1957, he joined the faculty at the University of California, Berkeley, where he remained for the rest of his career. Those of us who had the good fortune to study with him got to see Nick in a more personal light. There are experiences we all share and that we continue to recount when we see each other. Nick was an avid and unabashed sports fan who relished watching any athletic event that involved a ball, with the single exception of golf, the joy of which escaped him. The Berkeley football team was his great intercollegiate love, however, an enthusiasm so irrepressible that he was often seen sitting on the team bench during home games, invariably dressed in his signature sports jacket and tie. In 1993 he received the award for Distinguished Contributions to Slavic Studies from the American Association for the Advancement of Slavic Studies, for which he was obliged to travel to the convention. Although pleased to receive the honor, Nick was more than slightly dismayed that the convention banquet coincided with the "Big Game" (Berkeley versus Stanford), which he was going to miss. Students, ex-students, and visitors who came to his office in Dwinelle Hall would invariably be invited to go have coffee, always at the same little eatery on Bancroft Avenue, an establishment that came to be known locally as "Café Riasanovsky." A European gentleman in the best sense, he took each of us through a special rite of passage once we had finished our dissertation: we would be asked to join him for a drink, at which time we were invited to henceforth call our advisor "Nick." I don't know whether he realized how much we all looked forward to that coming-of-age moment, but none of us has ever forgotten.

Gary Marker

State University of New York, Stony Brook July 2011 